\title{
Aorto-ventricular tunnel
}

INSERM

\section{Source}

INSERM. (1999). Orphanet: an online rare disease and orphan drug data base. Aortoventricular tunnel. ORPHA:3400

Aorto-ventricular tunnel is a cong enital, extracardiac channel which connects the ascending aorta above the sinotubular junction to the cavity of the left, or (less commonly) right ventricle. 